\title{
Ocular myasthenia gravis after D-penicillamine administration
}

\author{
L JAY KATZ,' ROBERT L LESSER, ${ }^{2}$ JAMES R MERIKANGAS, ${ }^{3}$ AND \\ JOEL P SILVERMAN ${ }^{2}$
}

From the 'William and Anna Goldberg Glaucoma Service and Research Laboratories of the Wills Eye Hospital, Thomas Jefferson University, Philadelphia, PA 19107; the ${ }^{2}$ Department of Ophthalmology and Visual Science, Yale University School of Medicine, New Haven, CT 06510; and the ${ }^{3}$ Department of Psychiatry, Yale University School of Medicine, New Haven, CT 06510, USA

SUMMARY A 68-year-old black woman who was put on D-penicillamine therapy (250-500 mg per day, total dose $15 \mathrm{~g}$ ) for rheumatoid arthritis developed ocular myasthenia gravis. Two weeks after she discontinued D-penicillamine her signs and symptoms cleared with no other treatment. Review of previous cases and possible immunological mechanisms are discussed.

D-Penicillamine is an invaluable therapeutic agent in a variety of illnesses. It is an amino acid that is a pyridoxine antagonist produced by hydrolysis of penicillin.' Beneficial use has been made of its chelating properties in metallic toxic states whether exogenous ${ }^{2}$ (lead or mercury poisoning) or endogenous $^{3}$ (Wilson's disease). Since combination with cysteine yields a more soluble complex, it is potentially useful in cystinuria.$^{4}$ It has been used in rheumatoid arthritis, ${ }^{56}$ progressive systemic sclerosis, ${ }^{7}$ primary biliary cirrhosis, ${ }^{8}$ and haemophilic arthritis. " With increasing long-term use of D-penicillamine, immune mediated disorders such as myasthenia gravis, ${ }^{10-25}$ polymyositis, ${ }^{26}$ systemic lupus erythematosus, ${ }^{27}$ pemphigus, ${ }^{28}$ and Goodpasture's syndrome ${ }^{24}$ have occurred. This case report provides an illustrative example of reversible myasthenia gravis related to D-penicillamine therapy.

\section{Case report}

The patient was a 68-year-old black woman who had had rheumatoid arthritis for 30 years. After four months of D-penicillamine therapy $(250-500 \mathrm{mg} /$ day for a total dose of $15 \mathrm{~g}$ she noticed the onset of diplopia and right ptosis, which increased in severity at night. No other muscular weakness was noted.

On examination a right ptosis was observed, with

Correspondence to Robert L Lesser, MD, Department of Ophthalmology and Visual Science, Yale University School of Medicine, 333 Cedar Street, New Haven, CT 06510, USA. palpebral fissures in primary gaze measuring $5 \mathrm{~mm}$ on the right and $10 \mathrm{~mm}$ on the left. In primary gaze a left hypertropia of 20 prism diopters was recorded. Prolonged upward gaze for two minutes yielded a positive fatigue test with increasing droop of the right upper eyelid. Cogan's lid twitch sign was also present. Her vision was $20 / 20$ in both eyes. Her pupils, visual fields, slit-lamp appearances, and fundus were normal. Further neurological evaluation revealed no other focal or diffuse neuromuscular difficulty. A Tensilon (edriphonium) test was positive. Computerised axial tomography and lumbar puncture gave normal results. Laboratory tests gave normal values for thyroid function indices (T4-RIA, T3 uptake, TSH), serum vitamin $B_{12}$ and folate levels, and cerebrospinal fluid protein and glucose. The fasting blood glucose was $9.4 \mathrm{mmol} / \mathrm{l}(170 \mathrm{mg} / 100 \mathrm{ml})$. Complete blood count yielded a packed cell volume of $51 \%$ and a white cell count of $4 \mathrm{v} \times 10^{4} / \mathrm{l}$, with a normal differential count. No antibody to acetylcholine receptor was detected in her serum. Ten days after cessation of D-penicillamine signs and symptoms cleared. The patient never required anticholinesterase therapy.

\section{Discussion}

Several drugs may produce a myasthenia gravis-like state (Table 1). ${ }^{30}$ Since 1975, 10 case reports of 34 patients have strongly suggested an association between D-penicillamine and myasthenic gravis (Table 2). Patients with one of three underlying 
Table 1 Drugs inducing myasthenia gravis

\begin{tabular}{|c|c|c|}
\hline Antibiotics & $\begin{array}{l}\text { Colistin } \\
\text { Gentamicin } \\
\text { Kanamycin }\end{array}$ & $\begin{array}{l}\text { Neomycin } \\
\text { Polymyxin } \\
\text { Strepromycin }\end{array}$ \\
\hline Cardiovascular & $\begin{array}{l}\text { Oxprenolol } \\
\text { Practolol } \\
\text { Trimethaphan }\end{array}$ & \\
\hline Anticonvulsants & $\begin{array}{l}\text { Phenytoin } \\
\text { Trimethadione }\end{array}$ & \\
\hline Others & $\begin{array}{l}\text { Tetanus antitoxin } \\
\text { Oral contraceptives } \\
\text { D-Penicillamine }\end{array}$ & \\
\hline
\end{tabular}

diseases - rheumatoid arthritis (31 patients), Wilson's disease (two patients), and progressive systemic sclerosis (one patient) - underwent treatment with D-penicillamine and developed ocular myasthenia. Ptosis and diplopia were present in all cases in which symptoms and signs were reported. Serum globulin assay in more than $75 \%$ of those cases that were tested showed an acute, usually transient, elevation of antibodies to acetylcholine receptors 1141621243133 and, in another report, to striated muscle." Electromyographic tracing of the muscle response to double-step stimulation showed the typical myasthenia decremental response on repetitive nerve stimulation..$^{31}$

The differentiation of drug induced from spontaneous myasthenia gravis is usually on clinical grounds. In the drug induced type the onset of symptoms is usually six to seven months after starting therapy but ranges from less than one month to eight years. Muscular weakness usually resolves two to three months after stopping D-penicillamine, but recovery may occur after only several weeks or up to several years. It has been noted that two patients with myasthenia gravis induced by D-penicillamine had the HLA-DRI antigen in contrast to patients with idiopathic myasthenias, who typically have HLADR3 antigen. ${ }^{24}$ This difference suggests a different genetic background, that these are two distinct populations, and that the drug induced myasthenias are not simply unmasked from a susceptible stage. Moreover, recurrence after discontinuing Dpenicillamine has been reported. ${ }^{1031}$ Usually a concomitant improvement in electromyographic tracings ${ }^{25}$ and a decline in antiacetylcholine receptor antibodies ${ }^{21242531}$ are observed during clinical recovery, though the antibodies may remain raised..$^{32}$ Some patients may require oral anticholinesterase treatment. Rarely, plasmapheresis may be necessary for short-term maintenance. ${ }^{12}$

The pathogenesis of drug-induced myasthenia gravis is not clear. D-Penicillamine has no direct effect on cell membrane miniature end plate potential, ${ }^{31}$ amplitude, or ocular potential. ${ }^{34}$ The increase in serum antibodies to acetylcholine receptors, as in primary myasthenia gravis, ${ }^{35}$ implies a common pathogenesis. However, there are patients on D-penicillamine therapy who never develop antibodies $^{30}$ and there are also those who have antibodies but no myasthenic weakness. " Current theories on the mechanism of drug induced myasthenia gravis focus on altered immunological reactivity. A population of $B$ cell lymphocytes has apparently been induced to manufacture antibodies to the acetyl-

Table 2 Review of literature: myasthenia gravis following D-penicillamine treatment

\begin{tabular}{|c|c|c|c|c|c|c|c|}
\hline Author & Year & $\begin{array}{l}\text { No of } \\
\text { Patients }\end{array}$ & $\begin{array}{l}\text { Underlying } \\
\text { disease }\end{array}$ & $\begin{array}{l}\text { Duration of } \\
\text { treatment } \\
\text { (months) }\end{array}$ & $\begin{array}{l}\text { Time of } \\
\text { recovery } \\
\text { (months) }\end{array}$ & $\begin{array}{l}\text { Antibody to } \\
\text { acetylcholine } \\
\text { receptor }\end{array}$ & $\begin{array}{l}\text { Ocular } \\
\text { myasthenia }\end{array}$ \\
\hline Bucknall et al."' & 1975 & 4 & RA & $4,5,8,9$ & $1,1-1 / 3, \mathrm{NA}, \mathrm{NA}$ & NA & + \\
\hline Czlonkowski ${ }^{2 \prime}$ & 1975 & 1 & W & 13 & $1-1 / 2$ & NA & + \\
\hline Masters et al." & 1977 & $8 / 1(9)$ & RA/W & $\mathrm{NA} / 100$ & NA/NA & $4+, 1-/+$ & $\mathrm{NA} /+$ \\
\hline Gordon and Burnside ${ }^{14}$ & 1977 & 1 & RA & 4 & 7 & NA & + \\
\hline François et al." & 1978 & 1 & RA & 5 & 3 & NA & + \\
\hline Russell and Lindstrom" & 1978 & 1 & RA & 2 & 8 & + & + \\
\hline Atcheson and Ward ${ }^{17}$ & 1978 & 1 & RA & $1 / 15$ & 1 & - & + \\
\hline Vincent et al. ${ }^{3}$ & 1978 & 3 & RA & $6,20,9$ & NA & $3+$ & + \\
\hline Sundstrom and Schuna ${ }^{15}$ & 1979 & 2 & RA & 6,7 & $226 \mathrm{mo}$ & NA & + \\
\hline Keesey and Novom? & 1979 & 1 & RA & 9 & 8 & + & + \\
\hline Argovet al."3 & 1980 & 2 & RA & 10,18 & NA & + & + \\
\hline Rousseau and Diendonne ${ }^{13}$ & 1980 & 1 & RA & 6 & 2 & + & + \\
\hline Albers et al. ${ }^{14}$ & 1980 & 1 & RA & 7 & 6 & + & + \\
\hline Torres et al. ${ }^{\text {in }}$ & 1980 & 1 & PSS & 6 & $10 \mathrm{mo}$. & + & + \\
\hline Bocanegra et al. ${ }^{1 \times}$ & 1980 & 1 & RA & 3 & $2+$ & - & + \\
\hline Lang et al. ${ }^{12}$ & 1980 & 2 & RA & 6,7 & 6,6 & $1+1-$ & + \\
\hline O'Keefe et al.:- & 1985 & 2 & RA & 9,36 & $4,4+$ & $+1+$ & + \\
\hline
\end{tabular}

$\mathrm{RA}=$ rheumatoid arthritis. $\mathrm{W}=$ Wilson's disease. $\mathrm{PSS}=$ progressive systemic sclerosis. $\mathrm{NA}=$ not available. 


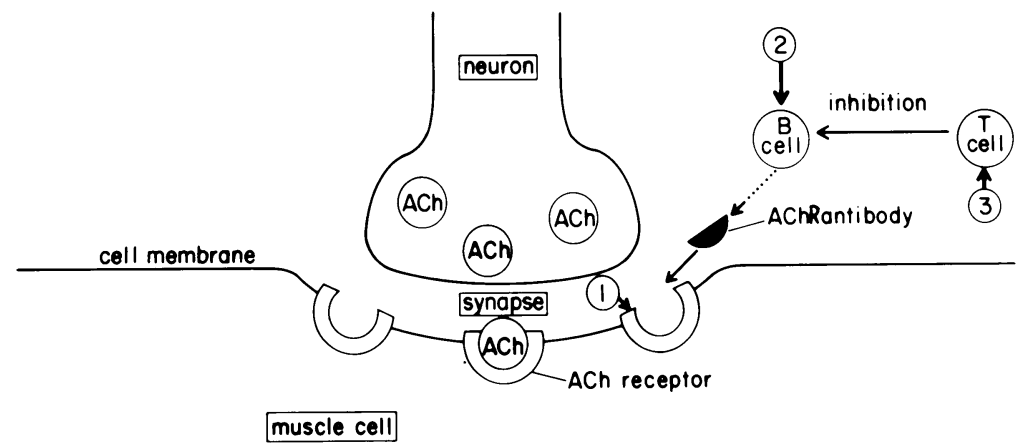

Fig. 1 Possible sites of penicillamine action: (1) Alteration of acetylcholine receptor. (2) Stimulation of B cell lymphocytes. (3) Inhibition of suppressor T cell lymphocytes.

choline receptors. This could be the result of several possibilities. (Fig. 1): (1) Acetylcholine receptor antigenic properties are altered, which would make self recognition more difficult. ${ }^{36}(2)$ There is a loss of suppressor $\mathrm{T}$ cell control over $\mathrm{B}$ cell production of antibodies. In-vitro studies demonstrate that Dpenicillamine decreases T cell division. ${ }^{37}$ (3) Direct stimulation of B cells, specific or non-specific, which would lead to increased levels of antibodies.

Although D-penicillamine has been extensively used for several disease states, most patients who develop myasthenia gravis are those with autoimmune disease, suggesting an inherent susceptibility to D-penicillamine. For example patients with rheumatoid arthritis have demonstrable defects in suppressor T cell function. ${ }^{3 *}$

An alternative explanation, not based on an immunological model, is that D-penicillamine stimulates prostaglandin $E_{1}$ synthetase to produce prostaglandin $E_{1}$, which occupies an allosteric site on the acetylcholine receptors. ${ }^{39}$ This may alter acetylcholine coupling with receptors.

With increasing use of D-penicillamine more patients will undoubtedly present with drug induced secondary myasthenia gravis. Since ocular features are predominant, ophthalmologists should bear in mind the association of myasthenia gravis with Dpenicillamine.

\section{References}

1 Levin WG. Heavy metal antagonist. In: Gillman A, Goodman $\mathrm{L}$, eds. The pharamacologic basis of therapeutics. New York: Macmillan, 1975: 919-20.

2 Cramer K. D-Penicillamine and N-acetyl-D-penicillamine in lead poisoning. Post Grad Med J 1974; 50 (suppl 2): 14-6.

3 Walshe JM. Penicillamine: a new oral therapy for Wilson's disease. Am J Med 1956; 21: 487-95.

4 Crawhill JC, Scowen EF, Walts RWE. Effects of penicillamine on cystinuria. Br Med J 1963; i: 588-90.

5 Jaffe IA. The effects of penicillamine on the laboratory parameters in rheumatoid arthritis. Arthritis Rheum 1965: 8: 1064-97.

$6 \mathrm{Jaffe}$ IA. Comparison of the effect of plasmapheresis and penicillamine on the level of circulating rheumatoid factor. Ann Rheum Dis 1963: 22: 71-6.
7 Thompson J, Milne JA. Two years of penicillamine for progressive systemic sclerosis - a case report. Post grad med J 1974: 50 (suppl 2): 36-8.

8 Epstein O, DeVilliers D, Jain J, Potter BJ, Thomas HC. Reduction of immune complexes and immunoglobulins induced by D-penicillamine in primary biliary cirrhosis. $N$ Engl J Med 1979: 300: $274-8$.

9 Corrigan JJ, Kolba KS, Gall EP, et al. Treatment of hemophilic arthritis with D-penicillamine: a preliminary report. Am J Hematol 1985: 19: 255-64.

10 Bucknall RC, Dixon AS, Glick EN, Woodland J, Zutschi DN Myasthenia gravis associated with penicillamine treatment for rheumatoid arthritis. $\mathrm{Br}$ Med $\mathrm{J} 1975$; i: 600-2.

11 Masters CL, Dawkins RL, Zilko PJ, Simpson JA, Leedman RJ Penicillamine-associated myasthenia gravis, anti-acetylcholine receptor and antistriational antibodies. Am J Med 1977; 63: 689-94.

12 Lang AE, Humphrey JG, Gordon DA. Plasma exchange therapy for severe penicillamine induced myasthenia gravis. $J$ Rheumatol 1981: 8; 303-7.

13 Rousseau JJ, Diendonne LG. Myasthenia gravis syndrome following administration of D-penicillamine. Acta Neurol Belg 1980; 30: 1246-50.

14 Albers JW, Hodach RJ, Kimmel DW, Treacy WL. Penicillamine associated myasthenia gravis. Neurology 1980); 30: 1246-50.

15 Sundstrom WR, Schuna AA. Penicillamine induced myasthenia gravis. Arthritis Rheum 1979; 22: 197-8.

16 Torres CF, Griggs RC, Baum J, Penn AS. Penicillamine-induced myasthenia gravis in progressive systemic sclerosis. Arthritis Rheum 1980; 23: 505-8.

17 Atcheson SG, Ward JR. Ptosis and weakness after the start of Dpenicillamine therapy. Ann Intern Med 1978; 89: 939-40.

18 Bocanegra T, Espinoaza LR, Vasey FB, Bermain BI. Myasthenia gravis and penicillamine therapy of rheumatoid arthritis. JAMA 1980; 244: 1822-3.

19 Gordon RA, Burnside JW. D-penicillamine induced myasthenia gravis in rheumatoid arthritis. Ann Intern Med 1977; 87: 578-9.

20 Czlonkowski A. Myasthenia syndrome during penicillamine treatment. Br Med J 1975; ii: 726-7.

21 Russell AS, Lindstrom JL. Penicillamine induced myasthenia gravis associated with antibodies to acetylcholine receptors. Neurology 1978: 28: 847-9.

22 Dawkins RL, Garlepp MJ. McDonald BL, Williamson J, Zilko PJ, Carran OJ. Myasthenia gravis and D-penicillamine. J Rheumatol 1981: 9: 169-74.

23 Delamere JP. Jobson S, Mackintosh LP. Wells L. Walton KW. Penicillamine induced myasthenia in rheumatoid arthritis: its clinical and genetic factors. Ann Rheum Dis 1983: 42: 500-4.

24 O'Keefe M, Morley KD, Haining WM, Smith A. Penicillamineinduced ocular myasthenia gravis. Am J Ophthalmol 1985: 99: $66-7$. 
25 François J, Verbraeken H, Gabriel P, et al. Myasthenia syndrome after peroral treatment with penicillamine. Ophthalmologica 1978: 177; 88-91.

26 Schraeder PL. Peters HA, Dahl DS. Polymyositis and penicillamine. Arch Neurol 1972: 27: 456-7.

27 Harpey JP. Caille B, Moulias R, Goust JM. Lupus-like syndrome induced by D-penicillamine in Wilson's disease. Lancet 1971: i: 292.

28 Benveniste M. Croufet J, Hombert JC, Lessana M, Camus JP, Hewitt J. Pemphigus induits pars la D-penicillamine dans la polyarthrite rheumtoide. Presse Med $1975 ; 4 ; 3125-8$.

29 Sternlieb I, Bennett B. Scheinberg IM. D-penicillamine induced Goodpasture's syndrome in Wilson's disease. Ann Intern Med 1975: 82: 673-6.

30 Argov Z, Mastalgia FL. Disorders of neuromuscular transmission caused by drugs. N Engl J Med 1979; 301: 4(09-13.

31 Argov T, Nicholson L. Fawcett PRW, Mastalgia FL, Hall M. Neuromuscular transmission and acetylcholine receptor antibodies in rheumatoid arthritis patients on D-penicillamine. Lancet 1980; i: 203.
32 Keesey $\mathbf{J}$, Novom S. HLA antigens in penicillamine induced myasthenia gravis. Neurology 1977; 29: 528-9.

33 Vincent A. Newson-Davis J. Martin V. Antiacetylcholine receptor antibodies in D-penicillamine myasthenia gravis. Lancet 1978; i; 254

34 Aldrich MS, Kim YI, Sanders DB. Effects of D-penicillamine on neuromuscular transmission in rats. Muscle Nerve 1979: 2: $180-5$.

35 Drachman DB. Myasthenia. N Engl J Med 1979; 301: 409-13.

36 Bever CT, Chany MW, Penn AS, Jaffe IA, Bock E. Penicillamine induced myasthenia gravis: effects of penicillamine on acetylcholine receptor. Neurology 1982; 32: 1077-82.

37 Merryman P. Jaffe IA. Effects of penicillamine on the proliferative response of human lymphocytes. Proc Soc Exp Biol Med 1978; 157: 155-8

38 Tosato G, Steinberg AD. Blaese RM. Defective EBV-specific suppressor T-cell function in rheumatoid arthritis. $N$ Engl $J$ Med 181; 305: 1238 .

39 Horrobin DF. Myasthenia and prostaglandin $\mathrm{E}_{1}$. J Rheumatol 1981: 8 (suppl): 169-74.

Accepted for publication 14 July 1989. 